\title{
HIERACIUM SYLVULARUM (ASTERACEAE) IN THE MORDOVIA STATE NATURE RESERVE: INVASIVE PLANT OR HISTORICAL HERITAGE OF THE FLORA?
}

\author{
Anatoliy A. Khapugin \\ Joint Directorate of the Mordovia State Nature Reserve and National Park «Smolny», Russia \\ Mordovia State University, Russia \\ e-mail: hapugin88@yandex.ru
}

Received: 04.03.2017

\begin{abstract}
Protected Areas are considered as one of the most appropriate tool for biodiversity conservation. However, invasion of alien species is one of the main and widely known problems of these territories. Therefore, the timely detection and prevention of the invasive species dispersal is one of the main tasks of researchers in Protected Areas. The European species Hieracium sylvularum was found in the Mordovia State Nature Reserve in 2012. In the following years, new locations have been discovered there. That is why the main traits of the ecology and biology, invasiveness level of the alien species were studied. An investigation of the five known H. sylvularum locations has been carried out in the Mordovia Reserve. Attention has been paid to the age-structure of the populations, the accompanying floras' composition and morphometrical parameters of the generative individuals. The environmental conditions of habitats were revealed and compared using phytoindication methods. The mass and germination of seeds, harvested on different locations, were studied. The results indicate that $H$. sylvularum is not an invasive species. This alien plant is able to reproduce primarily vegetatively. Probably, the population area can extend gradually on each location. Seed dispersal is difficult due to low germinability of seeds, despite of their significant number per plant. Based on obtained results, dry and semi-dry light lichen-moss-Pinus-forests have a higher invasibility by $H$. sylvularum. Therefore, perhaps, its new locations may be found especially in these habitats. Annual monitoring of the currently known locations of this alien plant is necessary in the Mordovia State Nature Reserve.
\end{abstract}

Key words: age structure, alien plant, Asteraceae, Hieracium sylvularum, Mordovia State Nature Reserve, morphometrics, phytoindication, population, Protected Area, seed germination

\section{Introduction}

Protected areas form a key component of the global response to environmental changes and degradation (Gaston et al., 2008; Conroy et al., 2011). These are contributing positively to biodiversity conservation (Leverington et al., 2010; Grebennikov, 2016; Ruchin \& Makarkin, 2017). However, in different parts of the world, biological diversity decreases (Butchart et al., 2010). Invasion of alien plants is a major driver that directly threatens biodiversity, even within the most effectively managed Protected Areas (Foxcroft et al., 2013). Invasive alien species form a major problem for managers of Protected Areas worldwide (Foxcroft et al., 2017). As a response, there are many publications devoted to alien plant performances in Protected Areas (e.g. Allen et al., 2009; Sennikov, 2012; Khapugin et al., 2013; Shcherbakov et al., 2013; Anastasiu et al., 2014; Burda et al., 2015; Fateryga \& Bagrikova, 2017) and their number is increasing rapidly.

Plant invasions by foreign troops are in fact so common and well documented that the Finn- ish botanist Panu Mannerkorpi coined a special term, polemochores, for them. According to Mannerkorpi (1944) this term refers to eastern or «Russian» plants introduced to Finland by Soviet troops during the 1939-1940 winter war. Similar introductions by German troops are well known and recently highlighted from Russia (e.g. Reshetnikova, 2016). They provide the explanation for the flora's richness of the socalled «wonderglades» of North-West Russia (Sennikov, 2009a). Historical veracity may be doubted as some of the supposed war-time introductions were already recorded in folk tradition. But the dispersal way is both possible and well documented. Special attention in this direction was paid to Hieracium species found on «wonderglades» primarily in North-West Russia (Sennikov, 2009a,b, 2012).

In Europe Hieracium sylvularum Jord. ex Boreau (H. grandidens Dahlst.) is the most widespread, common and abundant apomictic $\mathrm{Hi}$ eracium species used as an ornamental plant in Scandinavia, Finland, Baltic Countries and Rus- 
sia (Hylander, 1943; Sennikov, 2000, 2003a; Tyler, 2004). In Central Russia this plant is known from Moscow and Moscow Region (Sennikov and Novikov, 2006), Ivanovo Region (Sennikov, 2003b), Vladimir Region (Seregin, 2009), Kaluga Region (Reshetnikova et al., 2010), Kostroma Region (Sennikov \& Golubeva, 2014), Ryazan region (Sennikov \& Kazakova, 2015), Republic of Mordovia (only in the Mordovia State Nature Reserve (hereafter - MSNR)) (Sennikov et al., 2012). This species is native to Central Europe and the western parts of East Europe; the eastern edge of its distribution area is located in West Belarus (Sennikov, 1999, 2002). Hieracium sylvularum is capable to disseminate on short distances. It is considered as locally established in Sweden on several localities, as a good competitor, forming stands and having a frequent dispersal. Due to this fact it was assessed as invasive with a moderate impact on the native habitats and vegetation (Tyler et al., 2015). In Central Russia it was also assessed as an established and potentially invasive species (Mayorov et al., 2013), but not a pure invasive plant (Vinogradova et al., 2010). Sennikov \& Kazakova (2015) suggested more invasiveness of $H$. sylvularum in Central Russia compared with North-Western Russia. This once again emphasises the need for study of this species outside its native range.

Hieracium sylvularum is one of the most abundant park species of the genus Hieracium which has been considered as polemochore in Kaluga region (Reshetnikova, 2016), being found on the places of stationing of German army subdivisions during World War II. In 2012, H. sylvularum was found for the first time in MSNR on the base of revision of HMNR herbarium material (Sennikov et al., 2012). The species' occurrence in this Protected Area was explained by its former cultivation at the Igishev hill near inns known there in the XIX century. This is confirmed by Strelbitskiy's special map (1865-1871) of European Russia (Fig. 1).

Since 2012 special studies on this plant have been carried out to understand its status and origin of the locations in the MSNR. The aim of the present paper was to (i) study features of biology and ecology of $H$. sylvularum in the MSNR; (ii) determine the invasiveness degree of this alien species in the MSNR.

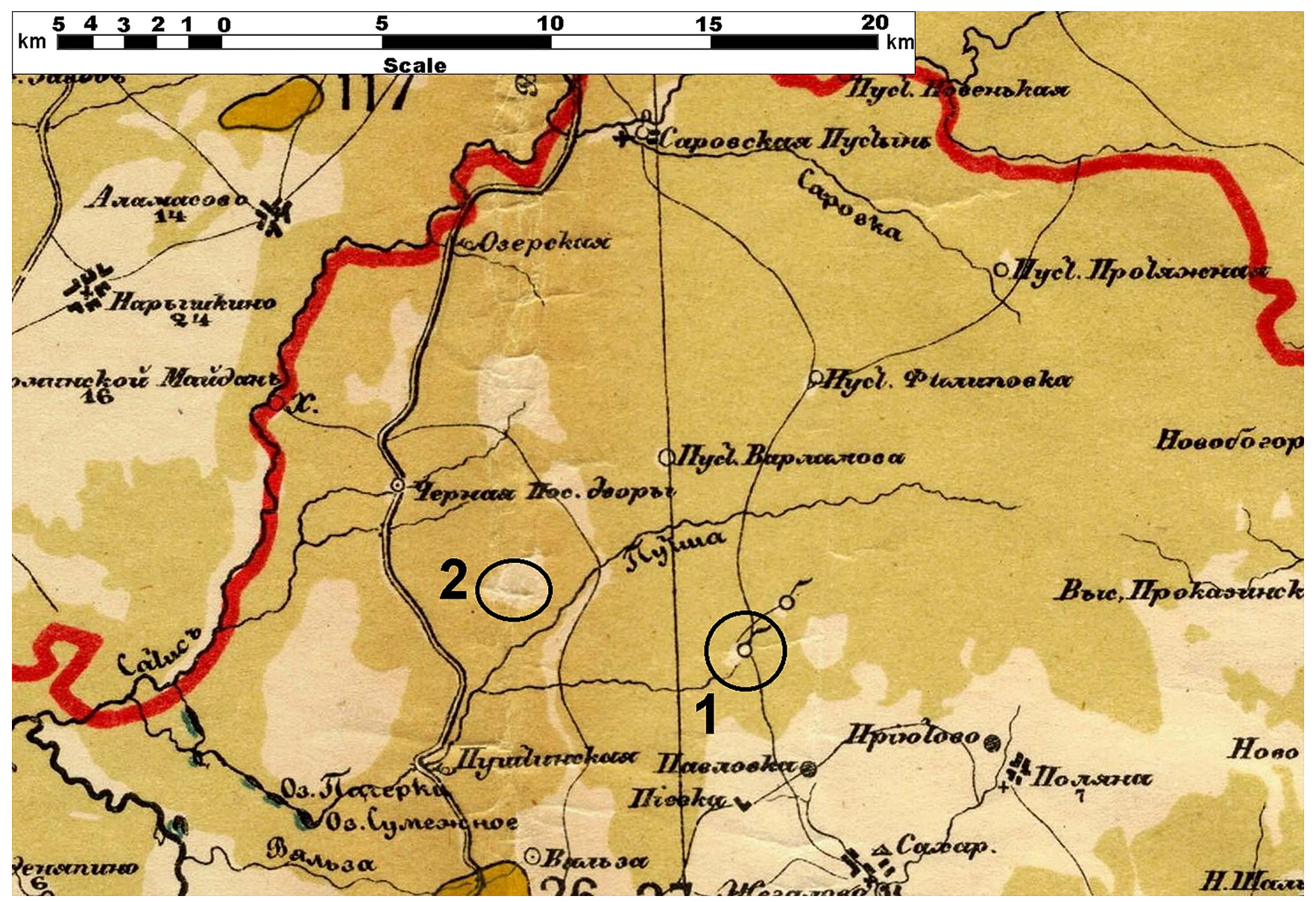

Fig. 1. Allocation of inns (area 1) at the Igishev hill in XIX century according to the special Strelbitskiy's (1865-1871) map of European Russia. Area 2 indicates the allocation of a Hieracium sylvularum population (location 5) currently known in the Mordovia State Nature Reserve and relatively outlying from Igishev hill. 


\section{Material and Methods}

The Mordovia State Nature Reserve is situated in Central Russia, at the southern boundary of the taiga natural zone $\left(54^{\circ} 42^{\prime}-54^{\circ} 56^{\prime} \mathrm{N} 43^{\circ} 04^{\prime}-\right.$ $43^{\circ} 36^{\prime} \mathrm{E}$; up to $190 \mathrm{~m}$ a.s.1., Fig. 2). Its total area is $321.62 \mathrm{~km}^{2}$. Soils are classified as predominantly sand in a varying degree of podsolization, lying on the ancient alluvial sands (Kuznetsov, 2014). The mean annual precipitation in this area varies from 406.6 to $681.3 \mathrm{~mm}$. The mean annual air temperature is $4.7^{\circ} \mathrm{C}$. The maximal temperature values are registered in July, and the minimal in February (Bayanov, 2015). Forest communities cover $89.3 \%$ of the total area. Pine (Pinus sylvestris L.) is the main forestforming wood species in the reserve. It forms pure or mixed forest communities in the south, central and western parts of the Mordovia Reserve. Birch (Betula pendula Roth) ranks the second place in the forested area in the Mordovia Reserve. Birch forests are encountered by patches together with pine forest areas. It forms predominantly secondary communities at logging sites and at burnt pine forest sites (Khapugin et al., 2016). Lime (Tilia cordata
Mill.) forests are encountered in the northern part of the Mordovia Reserve. They are predominantly secondary plant communities replacing pine ( $P i$ netum) and lime-spruce (Tilieto-Piceetum) forests. Oak (Quercus robur L.) forests cover a relatively small area in the floodplains of the river Moksha in the western part of the Mordovia Reserve. Spruce (Picea abies L.) forests are located predominantly in the floodplains of rivers and streams (Pushta, VyazPushta, Vorsklyay, Arga, etc.) and cover small areas.

In order to check the presence/absence of $\mathrm{Hi}$ eracium sylvularum at points currently known in MSNR, all locations listed in the herbarium (HMNR) labels were surveyed. Subsequently, population studies on the alien plant have been carried out on all five locations within this Protected Area (Fig. 2; Table 1).

Depending on the proportion of individuals of different age classes population types on the studied locations were defined according to Gorchakovskii \& Igosheva (2003). Plants of different age-state classes are shown in Fig. 3. The definition of age-state classes was conducted according to Rabotnov (1950):

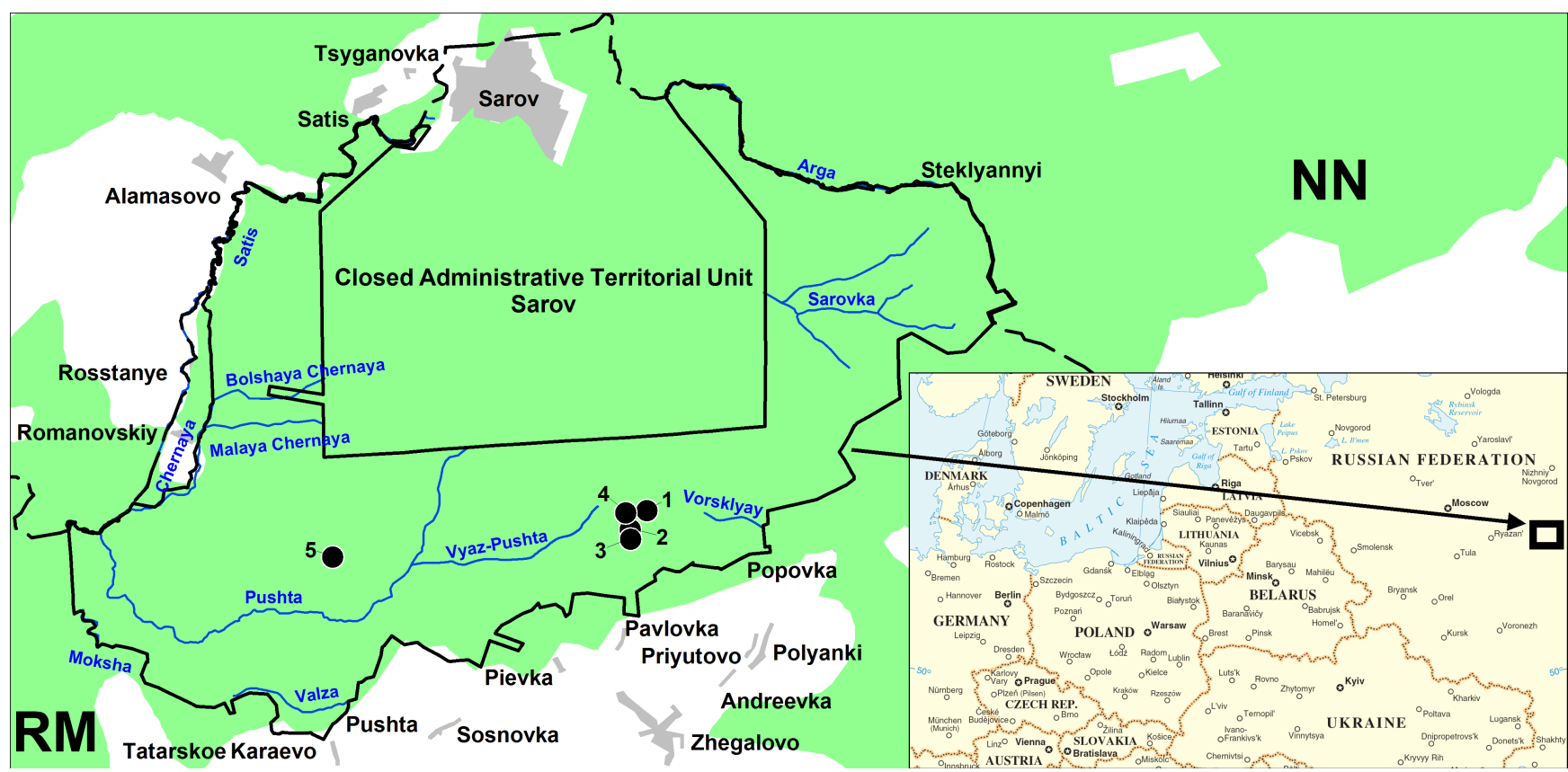

Fig. 2. Geographical location of the Mordovia State Nature Reserve in Europe. The numbers on the map of the Mordovia Reserve indicate the studied locations of Hieracium sylvularum. RM - Republic of Mordovia, NN - Nizhny Novgorod region (Map with modifications from web-site United Nations Geospatial Information Section: http://www.un.org/Depts/Cartographic/english/htmain.htm).

Table 1. Characteristics of Hieracium sylvularum locations in the Mordovia State Nature Reserve

\begin{tabular}{lccc}
\hline Location number & Forest compartment of Mordovia Reserve & Area, $\mathrm{m}^{2}$ & Counting method \\
\hline Location 1 & 343 & 4 & complete counting \\
Location 2 & 371 & 2 & complete counting \\
Location 3 & 371 & 60 & 2 square plots \\
Location 4 & 342 & 400 & 3 square plots \\
Location 5 & 360 & 600 & 3 square plots \\
\hline
\end{tabular}



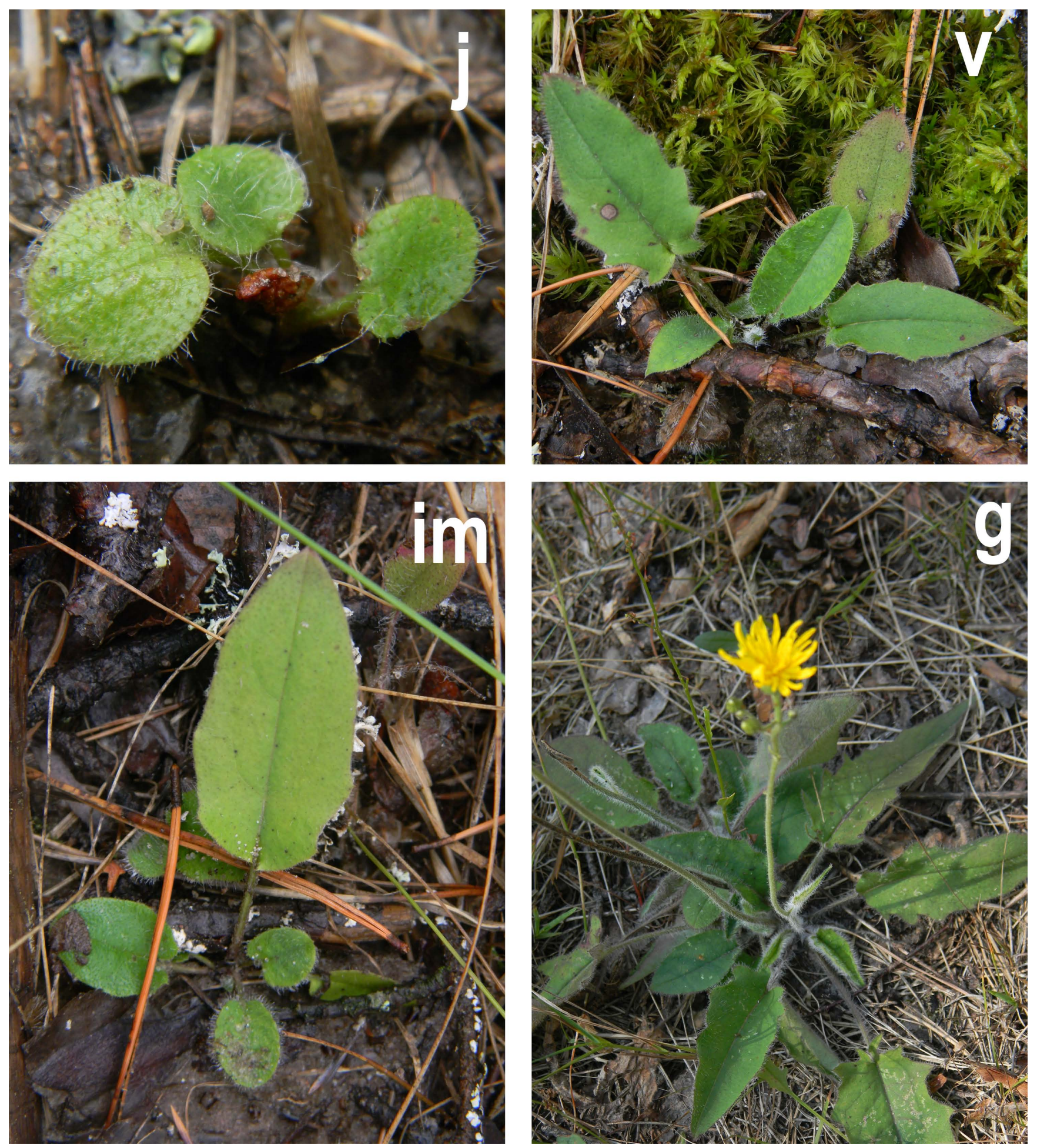

Fig. 3. Age-state classes of Hieracium sylvularum defined on locations in the Mordovia State Nature Reserve: j - juvenile, $\mathrm{im}$ - immature, $\mathrm{v}$ - mature vegetative, $\mathrm{g}$ - generative.

Juvenile individuals (j) are young plants transferred from cotyledon-caused to independent (autotrophic) nutrition. These individuals have no cotyledons, but their organisation is still simple; they have leaves of different forms and smaller than those of adults (i.e., mature vegetative and generative).

Immature individuals (im) are considered as a transition age-state class from juveniles to the mature vegetative plants. Individuals have been considered as immature if their rosettes consist- ed of leaves typical for both juvenile (oval, with short leafstalks, entire leaf margins) and mature vegetative (oblong-ovate, with truncate to sagittate base, basally with a number of large teeth) age-state classes.

Mature vegetative individuals (v) have the structure of the underground and aboveground organs typical for this species. The structure of vegetative organs corresponds to the generative age-state class, but the reproductive organs are still absent. 
Generative individuals ( $\mathrm{g}$ ) are considered as plants forming an inflorescence shoot with flower capitulae.

Hieracium sylvularum has been studied by counting all individuals on the locations 1 and 2; square plots $(1 \times 1 \mathrm{~m})$ were established on the locations 3, 4 and 5 (Table 1). Assessment of the $H$. sylvularum populations' status was carried out on the basis of the individual parameters of generative plants (height of plants, number and size of leaves per basal rosette; number of seeds formed per capitula; number of capitulae per individual (excl. location 2)), composition of the accompanying flora. The density (number of individuals per square metre) of $H$. sylvularum plants of each plot was assessed.

The composition of the accompanying flora (Appendix 1) was recorded within each locality for further comparison. The nomenclature and the taxonomy of the plant taxa are presented in accordance with The Plant List (2013) and Euro+Med Plantbase (Euro+Med, 2006+). Jaccard's similarity index $\mathscr{S}=100 \times C(A+B-C)$ was calculated, where $A=$ number of species in locality $A ; B=$ number of species in locality $B ; C=$ number of species shared between two ( $A$ and $B$ ) localities (Jaccard, 1901).

Square plots $(10 \times 10 \mathrm{~m})$ were established in order to conduct geobotanical surveys within each location. The abundance of each species has been estimated in accordance with the 7-point scale of Braun-Blanquet (Braun-Blanquet, 1964). Based on the obtained results, environment factors of habitats with $H$. sylvularum were estimated for conditions of Central Russia (like in Mordovia). Calculations were carried out according to Tsyganov's (1983) ecological scale, where ecological indicator values are arranged as intervals. It means that for each plant species we can define the range of its existence in relation to a concrete factor, for instance, soil nitrogen, moisture etc. Values could be evaluated in conventional units covering the total factor range from minimum up to maximum in relation to concrete species. Mean values were calculated using an algorithm suggested by Buzuk \& Sozinov (2009). Six environmental factors were examined: light (L), temperature (T), continentality $(\mathrm{C})$, moisture $(\mathrm{M}), \mathrm{pH}(\mathrm{R})$, soil nitrogen $(\mathrm{N})$.

In order to estimate germination characteristics, $H$. sylvularum seeds have been collected from each location, except for location 2, where generative plants were already without seeds. The seed weight was measured. For this purpose, samples of 50 randomly selected seeds were weighted to the nearest $0.1 \mathrm{mg}$. Then the seeds were kept in a refrigerator at $3-4{ }^{\circ} \mathrm{C}$ for 6 months (cold stratification). A germination experiment was performed by placing 50 seeds on a double layer of filter paper in growth chambers. These were incubated with temperatures $20-25{ }^{\circ} \mathrm{C}$ (average temperature of May - June in Mordovia). The light regime in the climate chambers simulated long day conditions with 16 hours of light and 8 hours of darkness (2000 lux). The seeds were considered as germinated when the radicle is longer than the seed, while the shoot is longer than half of the seed (Nikolaeva et al., 1985). Each experimental replication was conducted until the end of the seed germination in the growth chamber. Both the period from seed sowing to their germination and the germination period were registered. The energy period, germination energy, and seed germination were determined.

Statistical analyses were carried out using PAST 3.15 (Hammer et al., 2001) and Microsoft Excel.

\section{Results and Discussion}

Of the three locations noted by Sennikov et al. (2012), only the location at the Igishev hill could be confirmed. This location (number 4) seems most likely as the original place of Hieracium sylvularum's introduction in the MSNR. A survey of the second location (forest compartment 317, limepine forest, to north-east of Igishev hill) showed that this habitat of $H$. sylvularum was waterlogged. That, apparently, has caused its disappearance there. H. sylvularum has not been found in the lichen-pine forest in the 396th forest compartment, although appropriate habitats are present on this location. On the other hand, some new sites of $H$. sylvularum have been found. These are the locations 1, 2, 3 which may be considered as a result of dispersal of this alien plant from the Igishev hill. Also, a large population (ca. $600 \mathrm{~m}^{2}$ ) was discovered in the western part of the Mordovia Reserve (location 5). This is the most interesting location due to the ambiguousness of the origin of $H$. sylvularum. There is not any evidence of its cultivation there or in the neighbourhood. However, there is a large opening on the approximate place of this location (Fig. 1: area 2) according on the Strelbitskiy's special map (1865-1871) of European Russia. Clearly, further research is needed here. Data on the history of this territory before the establishing of the Mordovia Reserve will help to shed light on this issue.

Studies of the age structure of the populations demonstrated no dependence the composition of different-age individuals in relation to the population 
size. As seen in Fig. 4, the structure of the small (apparently the youngest) populations on the locations 1 and 2 are not similar, and neither differ the three largest populations (locations 3, 4, 5) by ratio of age-state classes. According to Gorchakovskii \& Igosheva's (2003) classification, only the small population on location 2 could be considered as «generative-oriented», with a proportion of generative individuals of $71.4 \%$. The small number of vegetative individuals including absent juvenile plants may be considered a threat to the extinction of $H$. sylvularum on this location, taking into account its location almost in a forest roadside. The population on location 5 may be considered bimodal with almost equal proportions of vegetative (juvenile, immature, mature vegetative) $(52.5 \%)$ and generative $(47.5 \%)$ individuals in age structure. The other $H$. sylvularum populations are considered vegetative-oriented with a variation of the generative individuals' proportion from $28.6 \%$ (location 4) to $41.2 \%$ (location 1 ). The density of plants varied on a very large range among different populations: from 5 (location 4) to 69 (location 3) individuals per $1 \mathrm{~m}^{2}$.

All five locations were compared on the basis of morphometrical parameters of generative $H$. sylvularum individuals (Table 3 ). The morphometrics of leaves was not measured on location 5. However, it can be seen that generative individuals on this location are different from those on all other $H$. sylvularum locations in the MSNR. In particular, generative plants have lower mean values of height, number of capitulae per individual and number of leaves per basal rosette. Moreover, values of these parameters were less variable on location 5 in comparison with values of the same parameters on other locations. The number of seeds per capitula is relatively equal on all locations; see Table 2.

The accompanying flora was revealed for all five H. sylvularum locations. It included 63 species of vascular plants, mosses and lichens from 55 genera and 33 families. Of these, three species (Pinus sylvestris L., Betula pendula Roth, Sorbus aucuparia L.) are obligatory components for all five locations; i.e., H. sylvularum always inhabits plant communities where the forest stand is presented by Pinus sylvestris and/or Betula pendula in different proportions with Sorbus aucuparia in the shrub layer. This is in accordance with studies of Krylov \& Reshetnikova (2009) who have proposed a high invasibility of pine forests to penetration of polemochores. Seven plant species (Convallaria majalis L., Fragaria vesca L., Luzula pilosa (L.) Willd., Melampyrum pratense L., Poa nemoralis L., Quercus robur L. (seed reproduction), Solidago virgaurea L.) were registered on four of the five locations. And nine species (Cladonia rangiferina (L.) F.H. Wigg., Frangula alnus Mill., Pilosella officinarum Vaill., Hieracium umbellatum L., Picea abies (L.) H. Karst., Pleurozium schreberii (Willd. ex Brid.) Mitt., Rubus idaeus L., R. saxatilis L., Trientalis europaea L.) were found on three locations. The above mentioned species could be considered as typical for habitats with $H$. sylvularum. The Jaccard's similarity index between accompanying floras varied from $13.2 \%$ (between location 1 and location 4) to $52.0 \%$ (between location 2 and location 3 ) (Table 3).

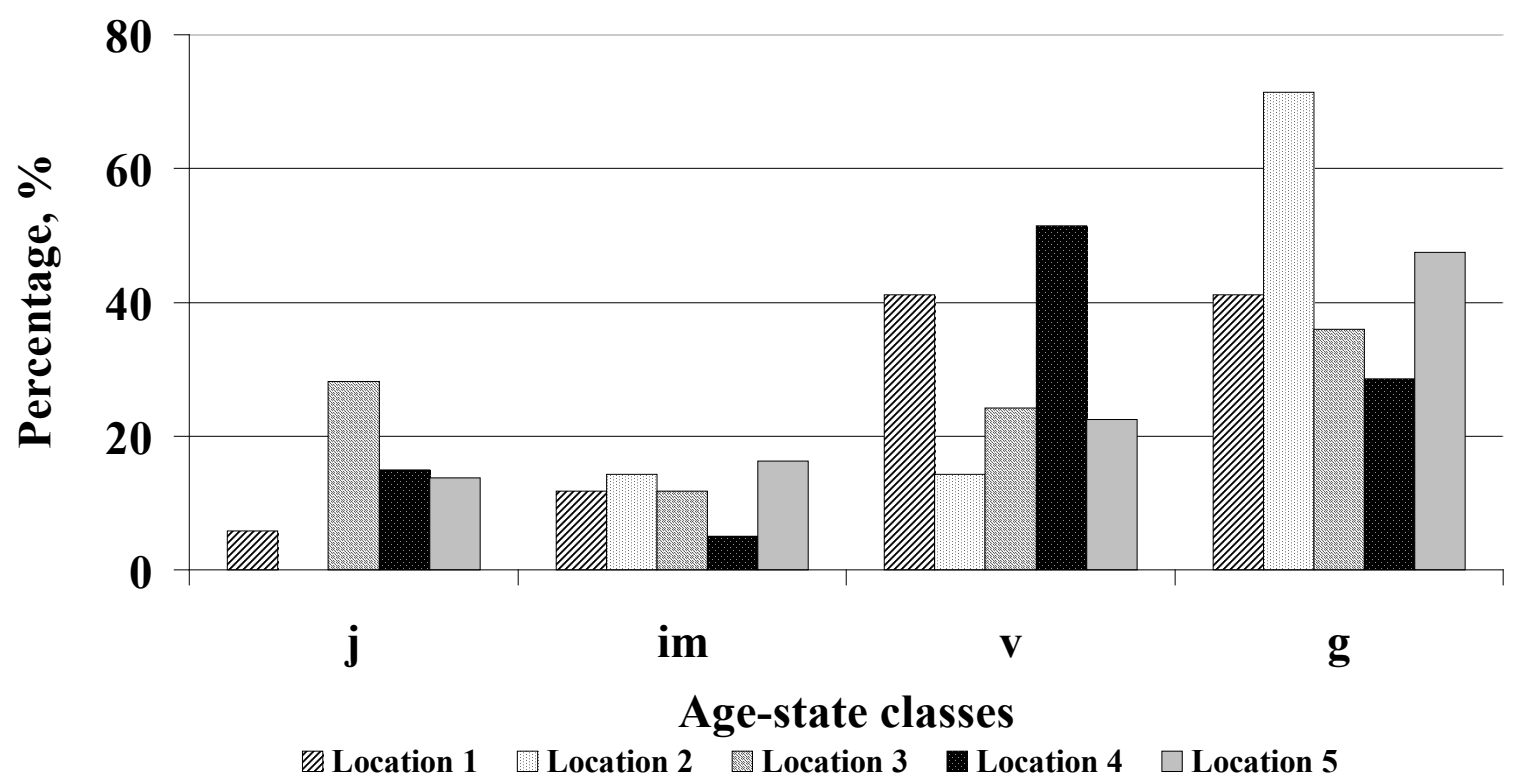

Fig. 4. Age structure in Hieracium sylvularum populations. Age-state classes of individuals: juvenile (j), immature (im), mature vegetative $(\mathrm{v})$, generative $(\mathrm{g})$. 
Table 2. Morphometrical parameters of generative individuals on Hieracium sylvularum locations in the Mordovia State Nature Reserve

\begin{tabular}{|c|c|c|c|c|c|c|c|c|c|c|c|c|c|c|c|}
\hline \multirow{2}{*}{ Parameter } & \multicolumn{3}{|c|}{ Location 1} & \multicolumn{3}{|c|}{ Location 2} & \multicolumn{3}{|c|}{ Location 3} & \multicolumn{3}{|c|}{ Location 4} & \multicolumn{3}{|c|}{ Location 5} \\
\hline & $M$ & $m$ & $\min -\max$ & $M$ & $m$ & $\min -\max$ & $M$ & $m$ & $\min -\max$ & $M$ & $m$ & $\min -\max$ & $M$ & $m$ & $\min -\max$ \\
\hline Height, cm & 45.6 & 2.6 & $35.0-52.0$ & 49.2 & 3.0 & $41.0-59.0$ & 43.4 & 2.0 & $24.0-60.0$ & 44.8 & 3.4 & $10.0-67.0$ & 38.7 & 1.1 & $28.0-57.0$ \\
\hline Number of capitulae & 6.3 & 0.9 & $3.0-10.0$ & 6.2 & 1.0 & $4.0-10.0$ & 7.0 & 0.4 & $3.0-10.0$ & 7.1 & 0.7 & $2.0-12.0$ & 5.6 & 0.4 & $2.0-13.0$ \\
\hline $\begin{array}{l}\text { Number of seeds } \\
\text { per capitula }\end{array}$ & 46.5 & 1.5 & $45.0-48.0$ & - & - & - & 48.5 & 0.9 & $43.0-54.0$ & 49.9 & 2.4 & $22.0-68.0$ & 49.7 & 3.0 & $36.0-64.0$ \\
\hline $\begin{array}{l}\text { Leaves number } \\
\text { per basal rosette }\end{array}$ & 5.6 & 0.5 & $4.0-7.0$ & 4.4 & 0.2 & $4.0-5.0$ & 4.9 & 0.2 & $3.0-6.0$ & 5.5 & 0.3 & $3.0-8.0$ & 4.0 & 0.1 & $3.0-6.0$ \\
\hline Leafstalk length & 5.2 & 0.4 & $4.0-8.0$ & 5.9 & 0.3 & $4.0-7.0$ & 4.7 & 0.2 & $2.0-9.0$ & 5.1 & 0.2 & $2.0-8.0$ & - & - & - \\
\hline Leaf length, cm & 9.3 & 0.6 & $6.0-13.0$ & 9.0 & 0.4 & $7.5-11.0$ & 7.5 & 0.2 & $5.0-11.0$ & 9.1 & 0.4 & $3.0-15.0$ & - & - & - \\
\hline Leaf width, cm & 3.7 & 0.1 & $3.0-5.0$ & 4.0 & 0.1 & $3.5-4.0$ & 3.2 & 0.1 & $2.0-5.0$ & 3.7 & 0.1 & $2.0-6.0$ & - & - & - \\
\hline
\end{tabular}

Note: $M$ - mean value, $m$ - error of the mean, $\min -\max -$ minimal-maximal values.

Table 3. Compositional similarity (Jaccard's index, $100 \times \mathrm{J}$ ) of the accompanying floras on five locations with Hieracium sylvularum in the Mordovia State Nature Reserve

\begin{tabular}{|l|l|l|l|l|}
\hline & Location 2 & Location 3 & Location 4 & Location 5 \\
\hline Location 1 & 30.0 & 23.5 & 13.2 & 25.6 \\
\hline Location 2 & & 52.0 & 24.4 & 47.1 \\
\hline Location 3 & & & 17.9 & 33.3 \\
\hline Location 4 & & & 31.8 \\
\hline
\end{tabular}

The data presented in Table 3 can be explained by environment conditions of the studied habitats. So, location 1 is situated on a roadside near a waterlogged shading alder (Alnus glutinosa (L.) Gaertn.) forest community, while location 4 is situated in a dry birch-dominant forest. It explains the low value of the Jaccard's similarity index (13.2\%). At the same time, locations 2 and 3 are situated not far from each other. That is why a high value of the Jaccard's similarity index (52.0\%) was registered.

The mean values for six environmental factors were calculated for the five locations with $H$. sylvularum (Appendix 2). These data may be used in further analyses of environment conditions using phytoindication methods. The data of Table 3 are closely similar to the results of comparison of environment factors' values in all studied habitats using the ecological scales of Tsyganov (1983) and Ellenberg et al. (2001). This comparison showed similar results according to both scales (Fig. 5). This coherence was demonstrated earlier as a result of comparison of habitat conditions for Neottianthe cucullata (L.) Schltr. in the same region (Khapugin et al., 2016). So, the maximal separation of location 4 from location 1 in the ordination diagram (Fig. 5) is consistent with the lowest value of the Jaccard's similarity index (Table 3). This applies to the allocation of the other points. For example, the highest similarity of location 2 and location 3 (Table 3 ) explains their close allocation in the ordination diagram (Fig. 5) according to both ecological scales. Location 1 is separated from all the others due to its higher shadiness and humidity. On the contrary, location 4 was the most lighted and acidic habitat. Finally, locations 2, 3 and 5 had more or less similar environmental conditions.

The mass of one achene varied from $0.24 \mathrm{mg}$ (location 5) to $0.48 \mathrm{mg}$ (location 4) (Table 5). Seed germination has been estimated visually through removing the germinated seeds from growth chambers. The seeds started to germinate on average on the fifth or seventh day of the experiment depending on their origin (Table 5). However, germination beginning has registered from day 4 to 13 in different replications. It demonstrates the disagreement in germination; this is especially related to seeds harvested on location 5. Perhaps, the low germination of the seeds harvested on location 5 has been caused by the smallest seed mass.

The energy period was determined experimentally by the comparison of the evenness of seed germination. For this purpose, the maximum number of germinated seeds per day was registered. The germination energy was determined as the ratio of the maximum number of germinated seeds per day to the total number of seeds in a replication. The picture of germination dynamics of $H$. sylvularum seeds from different locations shows that the maximum number of germinating seeds per day has been observed on the sixth (locations 3 an 4) or tenth (locations 1 and 5) day after the beginning of seed germination (Fig. 6). Therefore, the energy period was six days for seeds from locations 3 and 4 and ten days for those from locations 1 and 5. It is seen that 
the values of germination parameters of the seeds from locations 1 and 5 differ from the seeds harvested on locations 3 and 4 . Thus, the similarity of age structures of the population on location 1 with the population on location 5 , as well as the same similarity of age structure of the population on location 3 with the population on location 4 has been registered. It could indicate different life strategies of $H$. sylvularum in both couples of locations. This phenomenon needs further study.

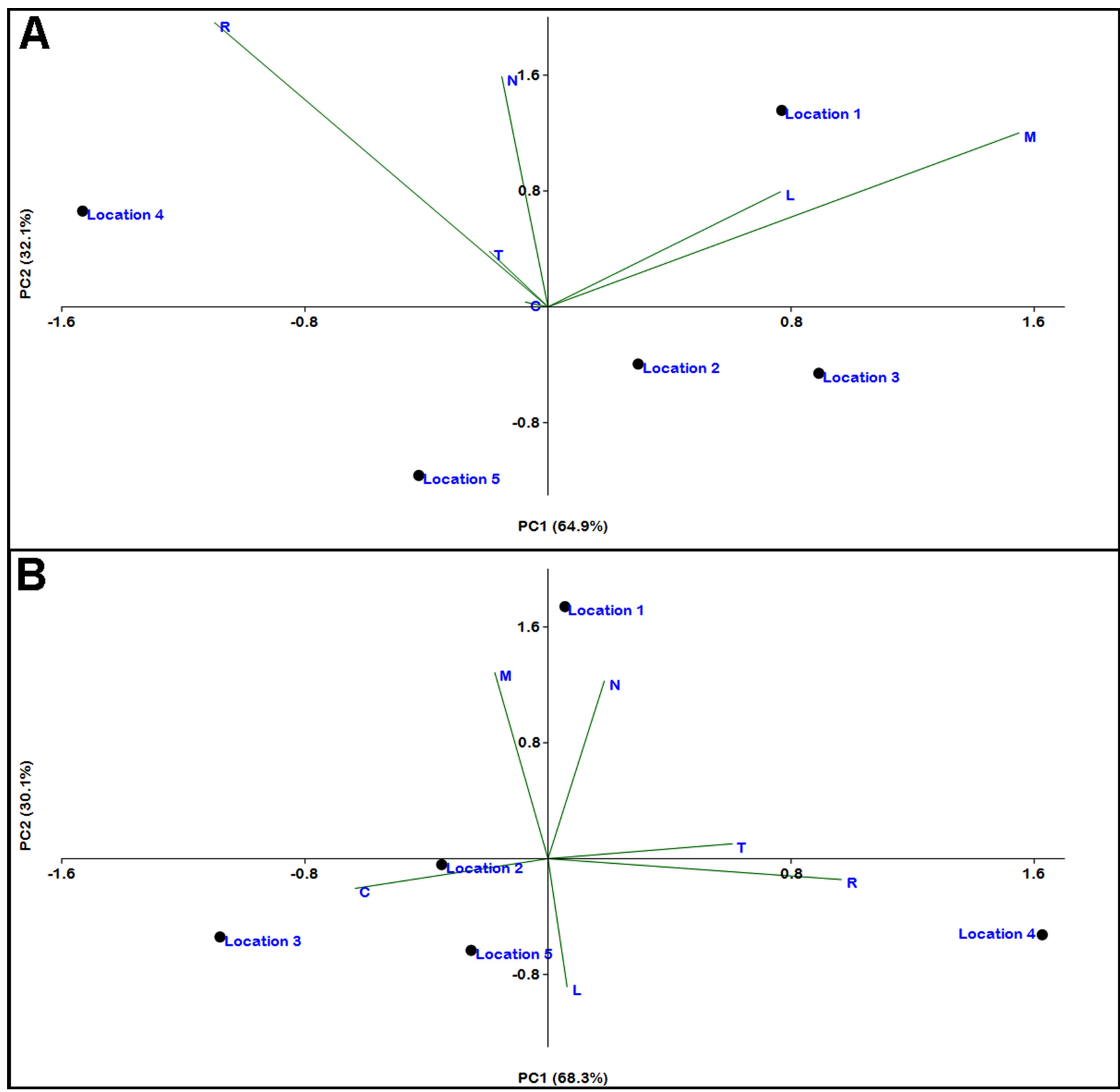

Fig. 5. Principal correspondence analysis (PCA) ordination diagram for the five locations with Hieracium sylvularum, based on mean environmental indicator values according to Ellenberg et al. (2001) (A) and Tsyganov (1983) (B); L - light (shading according to Tsyganov (1983)), T - temperature, $\mathrm{C}$ - continentality, $\mathrm{M}$ - soil moisture, $\mathrm{R}$ - soil $\mathrm{pH}, \mathrm{N}$ - soil nitrogen; original designations of environmental factors in Tsyganov (1983): light - LC, temperature - TM, continentality - KN, moisture - HD, reaction $-\mathrm{RC}$, soil nitrogen $-\mathrm{NT}$.

Table 5. Germination of Hieracium sylvularum seeds harvested from different locations in the Mordovia State Nature Reserve

\begin{tabular}{lllllll}
\hline Locations & $\begin{array}{l}\text { Seed } \\
\text { mass, mg }\end{array}$ & $\begin{array}{l}\text { Period before germi- } \\
\text { nation, days (limits) }\end{array}$ & $\begin{array}{l}\text { Energy pe- } \\
\text { riod, days }\end{array}$ & $\begin{array}{l}\text { Germination period } \\
\text { (limits), days }\end{array}$ & $\begin{array}{l}\text { Germination } \\
\text { energy, \% }\end{array}$ & $\begin{array}{l}\text { Seed } \\
\text { germination, } \%\end{array}$ \\
\hline 1 & $0.47^{1}$ & $7(5-9)$ & 10 & $20(17-22)$ & 4.0 & 5.7 \\
3 & $0.39^{2}$ & $5(4-5)$ & 6 & $18(10-21)$ & 2.5 & 7.5 \\
4 & $0.48^{3}$ & $5(4-5(13))$ & 6 & $18(9-22)$ & 2.4 & 7.1 \\
5 & $0.24^{4}$ & $7(4-10)^{*}$ & 10 & $16(9-22)^{*}$ & 1.8 & 4.9 \\
\hline
\end{tabular}

Note: ${ }^{1} \mathrm{n}=3,{ }^{2} \mathrm{n}=12,{ }^{3} \mathrm{n}=16,{ }^{4} \mathrm{n}=10 ;{ }^{*}$ - seeds did not germinate in one of the ten replications 


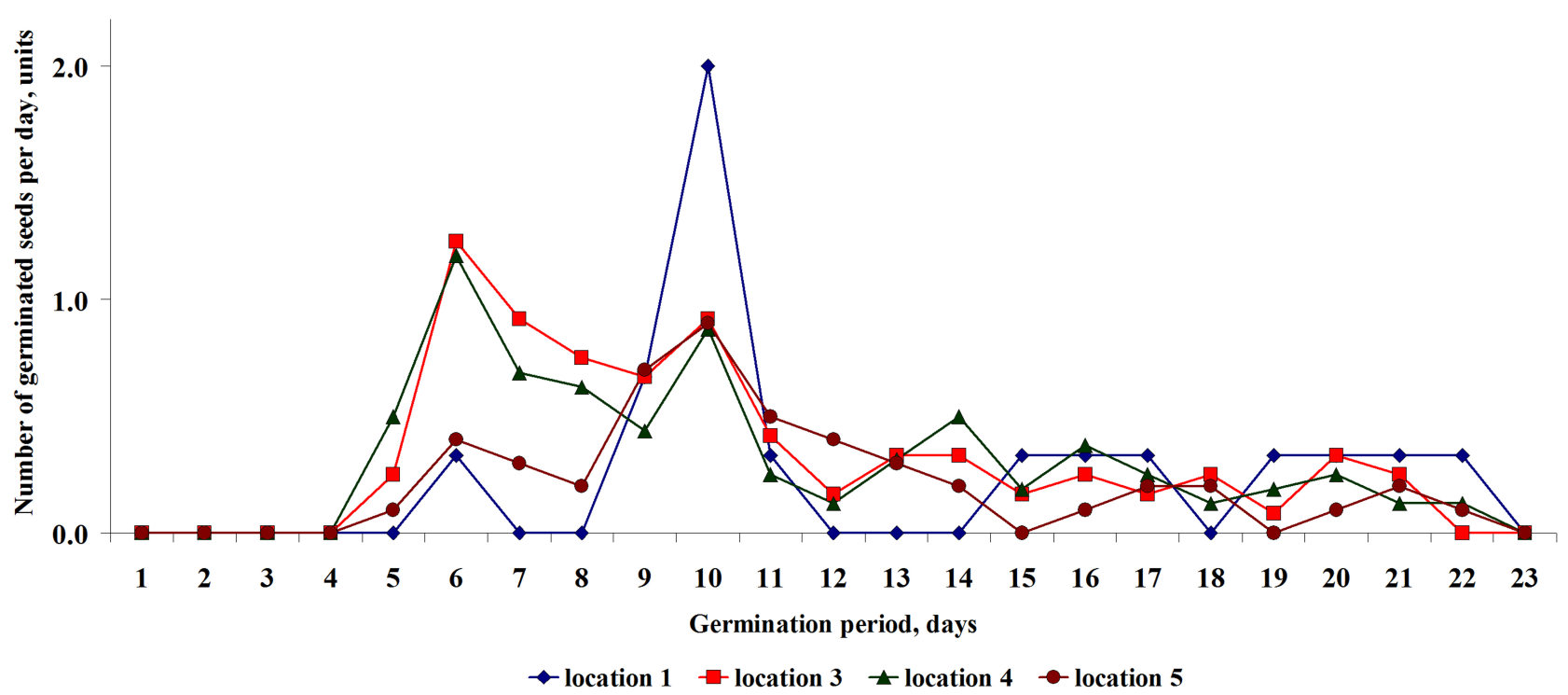

Fig. 6. Changes in the mean number of germinating Hieracium sylvularum seeds per day during the germination period for each location.

In general, $H$. sylvularum seeds demonstrated exclusively a low germinability in comparison with other Asteraceae plants: Bidens frondosa L., B. tripartita L. (Gladunova et al., 2016), Hieracium pratense (Panebianco \& Willemsen, 1976), H. aurantiacum L., H. praealtum L. (Bear et al., 2012). Sand substrate looks to be an appropriate substrate for seed germination of different alien and native species (e.g., Gladunova et al. 2014, 2016; Dutra et al. 2016; Radivojevic et al. 2016). Therefore, it may be suggested that the germination rate would be higher on a sand substrate, like where this plant grows in the Mordovia Reserve. On the other hand, the low germinability may be a confirmation of the horticultural (hybrid) origin of H. sylvularum in the Mordovia Reserve.

\section{Conclusions}

Hieracium sylvularum is not considered to be an invasive plant in Mordovia. It should be considered as a historical heritage of the flora which had been cultivated by human before the Mordovia Reserve was founded. Over more than a century this species has disseminated on short distances from the origin place (Igishev hill).

The currently known $H$. sylvularum populations are sustainable mainly due to vegetative reproduction. Its area can gradually extend at the place of growing. Active resettlement of this alien plant has never been observed in the MSNR, because the seeds have a low germinability despite of their significant number per plant (see Table 2).

New locations of H. sylvularum may be found in dry and semi-dry light lichen-moss-pine- forest communities due to their higher invasibility for this species. Although $H$. sylvularum is not considered as an aggressive invasive species, annual monitoring of its populations is needed, being an alien species.

\section{Acknowledgements}

I am grateful to Jacob Koopman (Choszczno, Poland) and two anonymous reviewers for their constructive comments and feedback on an earlier version of this paper.

\section{References}

Allen J.A., Brown C.S., Stohlgren T.J. 2009. Non-native plant invasions of United States National Parks. Biological Invasions 11: 2195-2207. DOI: 10.1007/ s10530-008-9376-1

Anastasiu P., Negrean G., Smarandache D., Liţescu S., Basnou C. 2014. Neophytes in Protected Areas. Case study: the Danube Delta Biosphere Reserve. Acta Horti Botanici Bucurestiensis 41: 41-68. DOI: 10.2478/ahbb-2014-0003

Bayanov N.G. 2015. Climate changes of the northwest of Mordovia during the period of existence of the Mordovia Reserve according to the meteorological observations in Temnikov. Proceedings of the Mordovia State Nature Reserve 14: 212-219. [In Russian]

Bear J.L., Giljohann K.M., Cousens R.D., Williams N.S.G. 2012. The seed ecology of two invasive Hieracium (Asteraceae) species. Australian Journal of Botany 60: 615-624. DOI: 10.1071/BT12058

Braun-Blanquet J. 1964. Pflanzensoziologie. Grundzüge der Vegetationskunde. 3 Aufl. Wien \& New York: Springer. $865 \mathrm{p}$.

Burda R.I., Golivets M.A., Petrovych O.Z. 2015. Alien species in the flora of the nature reserve fund of the flatland part of Ukraine. Russian Journal of Biological Invasions 6 (1): 6-20. DOI: 10.1134/ S2075111715010038 
Butchart S.H.M., Walpole M., Collen B., van Strien A., Scharlemann J.P.W., Almond R.E.A., Baillie J.E., Bomhard B., Brown C., Bruno J., Carpenter K.E., Carr G.M., Chanson J., Chenery A.M., Csirke J., Davidson N.C., Dentener F., Foster M., Galli A., Galloway J.N., Genovesi P., Gregory R.D., Hockings M., Kapos V., Lamarque J.F., Leverington F., Loh J., McGeoch M.A., McRae L., Minasyan A., Hernández Morcillo M., Oldfield T.E., Pauly D., Quader S., Revenga C., Sauer J.R., Skolnik B., Spear D., Stanwell-Smith D., Stuart S.N., Symes A., Tierney M., Tyrrell T.D., Vié J.C., Watson R. 2010. Global biodiversity: indicators of recent declines. Science 328: 1164-1168. DOI: $10.1126 /$ science. 1187512

Buzuk G.N., Sozinov O.V. 2009. Regression analysis in phytoindication (on example of D.N. Tsyganov's ecological scales). In: Botany (researches): Proceedings 37: 356-362. Minsk: Pravo i ekonomika. [In Russian]

Conroy M.J., Runge M.C., Nichols J.D., Stodola K.W., Cooper R.J. 2011. Conservation in the face of climate change: the roles of alternative models, monitoring, and adaptation in confronting and reducing uncertainty. Biological Conservation 144: 1204-1213. DOI: 10.1016/j.biocon.2010.10.019

Dutra F.A., Araujo M.M., Rorato D.G., Mieth P. 2016. Seed germination and seedling emergence of Luehea divaricata Mart. et. Zucc. in different substrates. Ciência Florestal 26: 411-418. DOI: 10.5902/1980509822744

Euro+Med. 2006+. Euro+Med PlantBase - the information resource for Euro-Mediterranean plant diversity. Retrieved from http://ww2.bgbm.org/EuroPlusMed/.

Fateryga V.V., Bagrikova N.A. 2017. Invasion of Opuntia humifusa and O. phaeacantha (Cactaceae) into plant communities of the Karadag Nature Reserve. Nature Conservation Research 2(4). DOI: 10.24189/ncr.2017.011

Foxcroft L.C., Pyšek P., Richardson D.M., Genovesi P. (eds.). 2013. Plant invasions in protected areas: patterns, problems and challenges. Dordrecht: Springer. 656 p. DOI: 10.1007/978-94-007-7750-7

Foxcroft L.C., Pyšek P., Richardson D.M., Genovesi P., MacFadyen S. 2017. Plant invasion science in protected areas: progress and priorities. Biological Invasions. DOI: 10.1007/s10530-016-1367-z

Gaston K.J., Jackson S.F., Cantú-Salazar L., Cruz-Piñón G. 2008. The ecological performance of Protected Areas. Annual Review of Ecology, Evolution, and Systematics 39: 93-113. DOI: 10.1146/annurev.ecolsys.39.110707.173529

Gladunova N.V., Khapugin A.A., Vargot E.V. 2016. Bidens frondosa L. (Asteraceae) in the Republic of Mordovia (Russia). Russian Journal of Biological Invasions 7: 129-136. DOI: 10.1134/S2075111716020053

Gladunova N.V., Vargot E.V., Khapugin A.A. 2014. Oenothera biennis L. (Onagraceae) in the Republic of Mordovia (Russia). Russian Journal of Biological Invasions 5: $12-17$.

Gorchakovskii P.L., Igosheva N.I. 2003. Monitoring of Orchid Populations in a Unique Area of Their Concentration in the Middle Urals. Russian Journal of Ecology 34 (6): 363-369. DOI: 10.1023/A:1027373915204

Grebennikov K.A. 2016. Study of biodiversity of nature reserves of the Russia in the digital age: experience and perspectives. Nature Conservation Research 1 (2): 1-10. [In Russian]
Hylander N. 1943. Die Grassameneinkömmlinge schwedischer Parke mit besonderer Berücksichtigung der Hieracia silvaticiformia. Symbolae Botanicae Upsalienses 7 (1): 1-432. [In German]

Jaccard P. 1901. Étude comparative de la distribution florale dans une portion des Alpes et du Jura. Bulletin de la Societe Vaudoise des Sciences Naturelles 37: 547-549. [In French]

Khapugin A.A., Vargot E.V., Chugunov G.G., Dementeva A.E. 2013. Additions and Notes to the Alien Flora of the Mordovian State Nature Reserve. Russian Journal of Biological Invasions 4 (3): 200-207.

Khapugin A.A., Vargot E.V., Chugunov G.G. 2016. Vegetation recovery in fire-damaged forests: a case study at the southern boundary of the taiga zone. Forestry Studies 64 (1): 39-50. DOI: 10.1515/fsmu-2016-0003

Krylov A.V., Reshetnikova N.M. 2009. Adventive component of the flora of the Kaluga region: naturalization of species. Botanicheskiy Zhurnal 94 (8): 1126-1148. [In Russian]

Kuznetsov N.I. 2014. The conditions of existence and main features of the vegetation cover structure on the territory of Mordovia State Reserve. 1939 year. Proceedings of the Mordovia State Nature Reserve 12: 79-195. [In Russian]

Leverington F., Costa K.L., Pavese H., Lisle A., Hockings M. 2010. A global analysis of protected area management effectiveness. Environmental Management 46: 685-698. DOI: 10.1007/s00267-010-9564-5

Mannerkorpi P. 1944. Uhtuan taistelurintamalle saapuneista tulokaskasveista. Annales Botanici Societatis ZoologicaeBotanica Fennicae «Vanamo». 20: 39-51. [In Finnish]

Mayorov S.R., Vinogradova Yu.K., Bochkin V.D. 2013. An illustrated catalogue of plants, escaping from cultivation in botanical gardens of Moscow, Russia. Moskva: Phyton XXI. 160 p. [In Russian]

Nikolaeva M.G., Razumova M.V., Gladkova V.N. 1985. Handbook on Germination of Dormant Seeds. Leningrad: Nauka. 348 p. [In Russian]

Panebianco R., Willemsen R.W. 1976. Seed Germination of Hieracium pratense, a Successional Perennial. Botanical Gazette 137 (3): 255-261.

Rabotnov T.A. 1964. Determination of age composition of species population within a community. In: Field Geobotany, vol. 3. Moscow: Akad. Nauk SSSR. P. 132-145. [In Russian]

Radivojevic L., Saric-Krsmanovic M., Umiljendic J.G., Bozic D., Santric L. 2016. The Impacts of Temperature, Soil Type and Soil Herbicides on Seed Germination and Early Establishment of Common Milkweed (Asclepias syriaca L.). Notulae Botanicae Horti Agrobotanici ClujNapoca 44: 291-295. DOI: 10.15835/nbha44110265

Reshetnikova N.M. 2016. The way of emergence of some Western European plant species in Kaluga Oblast - The pathway of the German army in 1941-1943. Russian Journal of Biological Invasions 7 (1): 62-68. DOI: $10.1134 /$ S2075111716010082

Reshetnikova N.M., Mayorov S.R., Skvortsov A.K., Krylov A.V., Voronkina N.V., Popchenko M.I., Shmytov A.A. 2010. Flora of Kaluga Region. An annotated list of vascular plants of the Kaluga Region. Moscow: KMK Scientific Press Ltd. 548 p. [In Russian]

Ruchin A.B., Makarkin N.V. 2017. Neuroptera and Raphidioptera in the Mordovia State Nature Reserve. Nature Conservation Research 2(2). DOI: 10.24189/ncr.2017.001 
Sennikov A.N. 1999. Preliminary results of the study of Hieracium (Asteraceae) in Belorussia. Botanicheskiy Zhurnal 84 (7): 119-128. [In Russian]

Sennikov A.N. 2000. Hieracium L. In: N.N. Tzvelev (ed.): Manual of the vascular plants of North-West Russia (Leningrad, Pskov and Novgorod regions). St. Petersburg: St. Petersburg State Chemical-Pharmaceutical Academy Press. P. 655-671. [In Russian]

Sennikov A.N. 2002. New data on occurrences of Hieracium (Asteraceae) in the Vitebsk Region of Byelorussia. Bulletin of Moscow Society of Naturalists 107 (6): 61. [In Russian]

Sennikov A.N. 2003a. Hieracium L. In: V. Kuusk, L. Tabaka, R. Jankevičienè (eds.): Flora of the Baltic countries. Compendium of vascular plants 3. Tartu: Institute of zoology and botany. P. 103-144. [In English and Russian]

Sennikov A.N. 2003b. New records of Hieracium (Asteraceae) in East Europe. Bulletin of Moscow Society of Naturalists 108 (6): 56-57. [In Russian]

Sennikov A.N. 2009a. Ado Haare (1934-2008), a prominent Estonian naturalist in Russia, and his theory of wonderglades. Memoranda Societatis pro Fauna et Flora Fennica 85: 61-67.

Sennikov A.N. 2009b. New records of apomictic species of $\mathrm{Hi}-$ eracium (Asteraceae) alien to Central Russia. Bulletin of Moscow Society of Naturalists 114 (3): 50-51. [In Russian]

Sennikov A.N. 2012. The bitter memory of a land: plantspolemochors in Eastern Fennoscandia and Northwest Russia. In: Problems of investigation of alien and synanthropic floras in Russia and neighboring countries: IV International Conference (Izhevsk, 4-7 December, 2012). Izhevsk. P. 182-185. [In Russian]

Sennikov A.N., Novikov V.S. 2006. Hieracium L. In: P.F. Maevskiy, Flora of middle belt of European part of Russia. Ed. 10. Moscow: KMK Scientific Press Ltd. P. 537-540. [In Russian]

Sennikov A.N., Silaeva T.B., Khapugin A.A. 2012. A synopsis of the genus Hieracium (Asteraceae) in the Republic of Mordovia. Bulletin of Moscow Society of Naturalists 117 (6): 77-78. [In Russian]
Sennikov A.N., Golubeva M.A. 2014. New records of Hieracium (Asteraceae) from the boreal zone of European Russia. Skvortsovia 1 (3): 248-256.

Sennikov A.N., Kazakova M.V. 2015. Additions and amendments in the genus Hieracium L. (Asteraceae) of the Ryazan and Vladimir Regions of European Russia. Skvortsovia 2 (2): 98-111.

Seregin A.P. 2009. Some species new to or rare in the Vladimir Region, 5. Bulletin of Moscow Society of Naturalists 114 (6): 62-64. [In Russian]

Shcherbakov A.V., Kiseleva L.L., Panasenko N.N., Reshetnikova N.M. 2013. Plants - living traces of the group «Center» army on Russian land. In: Flora and vegetation of Central Chernozem Region - 2013: Interregional Conference (Kursk, 6 April, 2013). Kursk. P. 198-202. [In Russian]

Strelbitsky I.A. (ed.). 1865-1871. Special map of European Russia with adjacent part of Western Europe and Asia Minor [Maps]. Scale: 10 versts per inch, 1:420 000. Saint-Petersburg: Voenno-topograficheskoe depo. 178 p. [In Russian]

The Plant List. 2013. Version 1.1. Retrieved 24 March 2016 from http://www.theplantlist.org/

Tsyganov D.N. 1983. Phytoindication of ecological regimes in the mixed coniferous-broad-leaved forest subzone. Moscow: Nauka. 197 p. [In Russian]

Tyler T. 2004. Reevaluation of the species of Hieracium sect. Hieracium that were described by Hylander from introduced populations in Scandinavian parks. Annales Botanici Fennici 41 (2): 103-131.

Tyler T., Karlsson T., Milberg P., Sahlin U., Sundberg S. 2015. Invasive plant species in the Swedish flora: developing criteria and definitions, and assessing the invasiveness of individual taxa. Nordic Journal of Botany 33: 300-317. DOI: 10.1111/njb.00773

Vinogradova Yu.K., Mayorov S.R., Khoroon L.V. 2010. The Black Book of Flora of Central Russia. Alien Plant Species in Ecosystems of Central Russia. Moscow: GEOS. 512 p. [In Russian]

Appendix 1. Floristic composition and projective cover of species according to Braun-Blanquet's scale in studied plant communities with Hieracium sylvularum in the Mordovia State Nature Reserve

\begin{tabular}{|c|c|c|c|c|c|}
\hline Designation of location & 1 & 2 & 3 & 4 & 5 \\
\hline Total number of species per locality & 28 & 24 & 14 & 32 & 26 \\
\hline Acer platanoides L. & & & & + & \\
\hline Achillea millefolium L. & & & & & $\mathrm{r}$ \\
\hline Antennaria dioica (L.) Gaertn. & & & & + & + \\
\hline Betula pendula Roth & 2 & 1 & 3 & 5 & 1 \\
\hline Calamagrostis epigejos (L.) Roth & & & & 2 & + \\
\hline Carex ericetorum Pollich & & & 1 & 1 & \\
\hline Carex leporina L. & $\mathrm{r}$ & & & & \\
\hline Carex pilosa Scop. & 2 & & & & \\
\hline Chamaecytisus ruthenicus (Fischer ex Woloszczak) Klásk. & & & & & $\mathrm{r}$ \\
\hline Chimaphila umbellata (L.) Nutt. & & & & & $\mathrm{r}$ \\
\hline Cladonia rangiferina (L.) F.H. Wigg. & & 1 & 1 & & 1 \\
\hline Convallaria majalis L. & 1 & 1 & & + & 2 \\
\hline Dryopteris cristata (L.) A. Gray & 2 & & & & \\
\hline Dryopteris filix-mas (L.) Schott & & $\mathrm{r}$ & & & \\
\hline
\end{tabular}




\begin{tabular}{|c|c|c|c|c|c|}
\hline Designation of location & 1 & 2 & 3 & 4 & 5 \\
\hline Total number of species per locality & 28 & 24 & 14 & 32 & 26 \\
\hline Epipactis helleborine (L.) Crantz & & & & $\mathrm{r}$ & \\
\hline Equisetum sylvaticum L. & + & & & & \\
\hline Festuca pratensis Huds. & & & & + & \\
\hline Fragaria vesca L. & 1 & 1 & & 1 & 1 \\
\hline Frangula alnus Mill. & 1 & 1 & 1 & & \\
\hline Galium mollugo L. & & & & + & + \\
\hline Genista tinctoria $\mathrm{L}$. & & & & & + \\
\hline Gymnocarpium dryopteris (L.) Newman & + & & & & \\
\hline Hieracium umbellatum $\mathrm{L}$. & & + & & + & + \\
\hline Hypericum perforatum L. & & $\mathrm{r}$ & & $\mathrm{r}$ & \\
\hline Juniperus communis L. & & & & $\mathrm{r}$ & \\
\hline Knautia arvensis (L.) Coult. & & & & $\mathrm{r}$ & \\
\hline Luzula pilosa (L.) Willd. & & 1 & 1 & 1 & 1 \\
\hline Lysimachia nummularia $\mathrm{L}$. & $\mathrm{r}$ & & & & \\
\hline Maianthemum bifolium (L.) F.W. Schmidt & 1 & & & & \\
\hline Malus sylvestris (L.) Mill. & & $\mathrm{r}$ & & & \\
\hline Medicago falcata $\mathrm{L}$. & & & & $\mathrm{r}$ & \\
\hline Melampyrum nemorosum L. & & & & 2 & \\
\hline Melampyrum pratense L. & & 1 & 1 & 1 & 1 \\
\hline Melica nutans $\mathrm{L}$. & & 1 & & 1 & \\
\hline Milium effusum L. & + & & & & \\
\hline Orthilia secunda (L.) House & & & & + & \\
\hline Phleum pratense L. & $\mathrm{r}$ & & & & \\
\hline Picea abies (L.) H.Karst. & 4 & & & & 4 \\
\hline Pilosella officinarum Vaill. & & 1 & & 2 & 1 \\
\hline Pimpinella saxifraga $\mathrm{L}$. & & & & & \\
\hline Pinus sylvestris L. & 2 & 5 & 4 & + & 3 \\
\hline Platanthera bifolia (L.) Rich. & & & & $\mathrm{r}$ & \\
\hline Pleurozium schreberii (Willd. ex Brid.) Mitt. & & 5 & 5 & & 4 \\
\hline Poa nemoralis L. & 1 & 1 & 1 & & 1 \\
\hline Polytrichum commune Hedw. & & 1 & & & 2 \\
\hline Populus tremula $\mathrm{L}$. & 1 & & & & \\
\hline Pteridium aquilinum (L.) Kuhn & 2 & & & & \\
\hline Quercus robur L. & 2 & + & + & $\mathrm{r}$ & \\
\hline Rubus idaeus L. & & 1 & 1 & & + \\
\hline Rubus nessensis Hall & + & & & & \\
\hline Rubus saxatilis L. & 1 & 1 & & & 1 \\
\hline Salix caprea $\mathrm{L}$. & & & & $\mathrm{r}$ & \\
\hline Solidago virgaurea L. & + & 1 & 1 & & 1 \\
\hline Sorbus aucuparia L. & 3 & 1 & 1 & 1 & 1 \\
\hline Sphagnum girghensohnii Russow & 1 & & & & \\
\hline Stellaria media (L.) Vill. & 1 & & & & \\
\hline Silene viscaria (L.) Jess. & & & & + & + \\
\hline Tilia cordata Mill. & 3 & & & & \\
\hline Trientalis europaea $\mathrm{L}$. & 1 & 1 & 1 & & \\
\hline Vaccinium myrtillus L. & 2 & + & & & \\
\hline Veronica chamaedrys L. & & & & + & \\
\hline Veronica officinalis L. & & & & 1 & 1 \\
\hline Vicia sylvatica $\mathrm{L}$. & & & & + & \\
\hline
\end{tabular}

Note: $\mathrm{r}-$ species is extremely rare, coverage is $<1 \%$; +- species rare, coverage is $1-2 \%$; $1-$ individuals are numerous, coverage is $2-5 \% ; 2$ - number of individuals is large, coverage is $5-25 \% ; 3$ - with any number of individuals, coverage is $25-50 \% ; 4$ - with any number of individuals, coverage is $50-75 \% ; 5$ - with any number of individuals, coverage is more than $75 \%$. 
Appendix 2. Mean values of environmental factors for Hieracium sylvularum in the Mordovia State Nature Reserve according to ecological scales of Tsyganov (1983) and Ellenberg et al. (2001)

\begin{tabular}{|c|c|c|c|c|c|c|}
\hline & Light & Temperature & Continentality & Moisture & Reaction & Nitrogen \\
\hline \multicolumn{7}{|c|}{ According to Tsyganov (1983) } \\
\hline Location 1 & 4.9 & 7.9 & 8.4 & 13.5 & 5.5 & 5 \\
\hline Location 2 & 4.5 & 7.8 & 8.5 & 12.8 & 5.1 & 4.3 \\
\hline Location 3 & 4.7 & 7.7 & 8.4 & 13.2 & 4.9 & 4.1 \\
\hline Location 4 & 4.1 & 8 & 8.5 & 11.9 & 6.4 & 4.7 \\
\hline Location 5 & 4.1 & 7.8 & 8.4 & 12.1 & 5 & 4.3 \\
\hline Mean & 4.5 & 7.8 & 8.4 & 12.7 & 5.4 & 4.5 \\
\hline \multicolumn{7}{|c|}{ According to Ellenberg et al. (2001) } \\
\hline Location 1 & 5.3 & 4.7 & 5.0 & 5.7 & 4.0 & 4.5 \\
\hline Location 2 & 6.0 & 4.3 & 5.3 & 4.8 & 3.7 & 3.6 \\
\hline Location 3 & 6.1 & 4.1 & 5.9 & 4.7 & 3.1 & 3.1 \\
\hline Location 4 & 6.2 & 5.5 & 4.3 & 4.3 & 5.6 & 3.6 \\
\hline Location 5 & 6.1 & 4.2 & 5.3 & 4.5 & 4.0 & 3.3 \\
\hline Mean & 5.9 & 4.5 & 5.2 & 4.8 & 4.1 & 3.6 \\
\hline
\end{tabular}

Note: Original designations of environmental factors in Tsyganov (1983): light - LC, temperature - TM, continentality $-\mathrm{KN}$, moisture $-\mathrm{HD}$, reaction $-\mathrm{RC}$, soil nitrogen $-\mathrm{NT}$

\title{
HIERACIUM SYLVULARUM (ASTERACEAE) В МОРДОВСКОМ ГОСУДАРСТВЕННОМ ПРИРОДНОМ ЗАПОВЕДНИКЕ: ИНВАЗИОННЫЙ ВИД ИЛИ ИСТОРИЧЕСКОЕ НАСЛЕДИЕ ФЛОРЫ?
}

\author{
А. А. Хапугин \\ Объединенная дирекиия Мордовского государственного природного заповедника имени П.Г. Смидовича \\ и национального парка «Смольный», Россия \\ Мордовский государственный университет имени Н.П. Огарева, Россия \\ e-mail: hapugin88@yandex.ru
}

Особо охраняемые природные территории считаются одним из наиболее приемлемых и удобных способов сохранения биоразнообразия. Инвазии чужеземных видов являются одной из основных и широко известных проблем на этих территориях. Поэтому своевременное распознавание инвазионных видов и предотвращение их расселения являются основной задачей научных сотрудников особо охраняемых природных территорий. В 2012 г. в Мордовском государственном природном заповеднике был обнаружен западноевропейский чужеземный вид Hieracium sylvularum. В последующие годы здесь были выявлены новые местонахождения этого вида. Поэтому были изучены основные черты экологии, биологии, уровень инвазионной активности H. sylvularum. Были проведены исследования чужеземного вида во всех известных местонахождениях в Мордовском заповеднике. Были изучены возрастная структура популяций, состав сопутствующей флоры, морфометрические параметры генеративных особей. Были выявлены и сравнены экологические условия изученных местообитаний с использованием методов фитоиндикации. Проведены исследования массы и всхожести семян, собранных в разных местонахождениях. Полученные результаты показали, что $H$. sylvularum не является агрессивным инвазионным видом. Вероятно, вид способен к размножению преимущественно вегетативным путем, в результате чего площадь популяций чужеземного вида может постепенно увеличиваться в каждом из местообитаний. Семенное размножение затруднено вследствие низкой всхожести семян, несмотря на их значительное количество на одно растение. Сухие и полусухие светлые мохово-лишайниковые сосновые леса более инвазибельны для $\mathrm{H}$. sylvularum, на основании полученных данных. Поэтому, вероятно, новые находки вида ожидаемы именно в таких местообитаниях. Необходим ежегодный мониторинг популяций $H$. sylvularum, известных к настоящему времени, так как он является чуждым по отношению к местной флоре Мордовского заповедника.

Ключевые слова: Asteraceae, Hieracium sylvularum, возрастная структура, Мордовский государственный природный заповедник, морфометрия, особо охраняемая природная территория, популяция, прорастание семян, фитоиндикация, чужеземный вид 